UDC 81'373.45

DOI: $10.17223 / 19996195 / 45 / 2$

\title{
METAPHORICAL MODELING OF RUSSIA'S IMAGE IN THE MASS MEDIA: THE CASE OF AMERICAN PRESS
}

\author{
M. Ilyushkina, A. Chudinov
}

The research was carried out within the framework of the grant of the Russian Foundation for Basic Research: project No. 19-012-00465 A "Linguopolitical Personology: A Cognitive Turn".

\begin{abstract}
The article is focused on the analysis of metaphorical modeling of the Russian image in the modern U.S. media texts. The undertaken research stresses the importance of metaphorical modeling in understanding the national world picture and national stereotypes. Basic metaphorical models reveal three negative prevailing trends in representing the image of Russia and contemporary Russian political discourse such as negative image of the Russian leader; negative image of Russia; negative relations between Russia and the United States (based on the metaphor "Image of the Enemy"). The research in metaphorical modeling of Russia in mass media of the United States of America is up-to-date as it gives grounds for classifying the material within situational, contextual and cultural aspects. It is also argued that some metaphorical models are common while others are culturally peculiar and totally stereotyped. The core of the research includes the texts addressed at readers from diverse academic backgrounds, methods of continuous sampling and comparative analysis were applied. The investigation of a wide range of political discourses leads to in-depth study of the national culture and world perception as it allows to identify the functions of particular metaphorical models, the identification of source domains of metaphorical expressions, the relationship between metaphor and discourse, and the priming of metaphors. Moreover, a number of approaches to and exploitations of political metaphors in modeling the image of Russia in the American mass media, including conceptual metaphor theory and cognitive approaches are discussed, explored and critiqued using corpus data. The present research also includes corpus linguistic studies of different aspects of metaphor, which investigate its linguistic and semantic properties and relate them to current theoretical views. The article demonstrates the need for naturally-occurring language data to be used in the development of metaphor theory, and shows the value of corpus data in this work. Thus, the ways of researching metaphor from different perspectives is carried out especially through corpus linguistics. Identifying metaphorical languageuse is one of the challenges facing natural language processing.
\end{abstract}

Keywords: metaphorical modeling; mass media; image; stereotype; national world picture; Russia; The United States of America.

\section{Introduction}

One of the most effective means of interpreting the conceptual reality in linguistics at the modern stage of its development, which is also a fragment of the world's language picture is a conceptual metaphor. 
While studying conceptual metaphors of any language, the peculiarities of national consciousness and national picture of the world, reflected in the national language are explored at the same time. There are many components in the system of conceptual metaphors of every nation that have a vivid national specificity. Many of these metaphors "guide" the perception of reality, the understanding of the phenomena and events that occur. They also determine the national characteristics of the communicative behavior of people.

The study of linguistic metaphorical use of words in the media and the need to systematize and describe the metaphorical units has led to the introduction of the term metaphorical modeling.

\section{Corpus of study}

In the study of metaphorical modeling in this paper, we turn to the study of texts of both printed and on-line American media. In general, 253 metaphorical items recorded in 54 journalistic texts were analyzed. Basically, the material used for the study of texts was published in the period mainly due 2010-2016 (The American Interest, The American Thinker, The Boston Globe, The Daily Signal, Defensenews, The Forbes, The Globalist, The Impudent Observer, The Los Angeles Time, The National Interest, The New York Times, The Newsweek International, The San Francisco Chronicle, Stratfor, The Time, The Washington Times, The Washington Post, The World Affairs Journal). Journalistic texts addressed the readers with different interests, background and intellectual requests were in the center of our attention.

The most important conclusions and outcomes of the research on three positions are formulated: the metaphorical image of the leader of a foreign state, the metaphorical description of the country, the metaphorical image of relations with a foreign country. Each situation is illustrated by a sufficient number of examples.

The analysis of metaphorical models confirms Anatoly Chudinov's idea that a political metaphor is capable of performing several functions simultaneously. In this case, a political metaphor is used in modern American press to create an image of "a foreign country", performing at the same time 9 out of 12 possible functions. These functions are known as communicative, pragmatic, figurative, instrumental, hypothetical, modeling, popularization, argumentative, as well as a function of the increment information [1. P. 106-113].

\section{The image of Russia in the modern American press}

The aim of the research is to describe and analyze the metaphorical models, most common for the American press in terms of their characteriza- 
tion and evaluation of domestic and foreign policy of Russia. Any interest in the political situation in Russia can be explained by the fact that, on the one hand, the modern published editions take into account the demands of the society while the society sees its inherent role in the political involvement. On the other hand, the scandals and intrigues taking place on the Russian political arena give grounds for expressiveness, evaluation, which is an integral part of the language in the press.

There are three topics that are frequently discussed in the American press about Russia / Firstly, the Russian President, Vladimir Putin`s identity, political development inside and outside the country. As for the foreign policy, in most cases, Russian-American relations are described, and only during the last two years relations with other countries (the Ukraine, Syria, Turkey) have been reasonably under consideration more often. The article presents a study of metaphorical models, reflecting the political reality of Russia of the 21 st century.

\section{Metaphorical portrait of the Russian President in the American press}

We have identified a metaphorical model that totally reflects the stereotypical perception of the Russian president by the average American: The President of Russia is the Tsar. This model is not the only one, but the most common in the American press. It provides a complete and accurate representation of the Russian President's image in the minds of the American readers.

According to the research carried out by Chudinov and Sheigal, the "royal metaphor" [2. P. 214] is a common phenomenon in the newspaper text. However, it should be noted that the United States is a country, which has never experienced a monarchical system of governing. In 54 American texts no examples of comparison of the US President with the monarch were observed. The metaphorical description of the US head of the state in terms of the absolute power of the American media is not being used at all. In the minds of Americans, the image of the national political leader is not associated with the monarchical system of government and autocracy.

Although Russia is a democratic republic, in the American press it is possible to find textual examples of possible changes of the mode of governing. One of the examples is that the power of the head of the state in Russia is inherited. Vladimir Putin is often called the successor of the first Russian President Boris Yeltsin. E.g.: Vladimir Putin, Yeltsin's successor, is about to find out other, less heroic ways in which Boris Yeltsin may be remembered (Newsweek International. 25.04.2011). Americans are convinced that Vladimir Putin will hand over the power to his successor in the same way. E.g.: Who will succeed Vladimir Putin? [3].

Power is something sacred, deified, for this is the condition for legitimizing the power of the monarch. Power in Russia is not considered to be a 
derivative of any other authority or voters. The President of Russia in the American media is often portrayed as a ruler endowed with unlimited power. The number of metaphorical usage pertaining to the analyzed metaphorical model is 101 .

American newspapers often refer to the President Vladimir Putin as emperor (emperor), monarch ("monarch"), king ("csar" / "tsar" / "tzar"). The monarchical model of perception of the head of Russia shapes in the minds of the American society the idea of the political endless power of the Russian President. This trend can be explained by the fact that the historicism of the "tsar of all Russia" has formed a stereotype in the minds of Americans, and periodicals purposefully consolidate national stereotypes in mind. "The Czar of all Russians" is the name of the Russian president in one of the issues of the on-line magazine "The American Thinker". E.g.: Here comes the Czar of all Russians to rescue Christian civilization from a bloody nightmare in Syria and Iraq [4].

The head of the presidential republic is characterized by unusual powers: absolute, sovereign and permissiveness. Absolute monarchy assumes absolute power of the head of the state and the lack of constitutional order. The monarch plays the most important role in governance, legislation and justice.

In the magazine "Newsweek" in the title of the article "Putin the Great (Russia's President)" the allusion to Peter the Great is quite obvious. This comparison of Vladimir Putin with the Russian Emperor Peter the Great is very symbolic. E.g. He is following the traditional, expansionist Russian policy of Peter the Great [5]. Mr. Putin - is a student of Peter the Great [6].

Although the Russian Federation is a democratic state with an elected principle of power transfer, the President is elected through a popular vote every 6 years, "the royal metaphor" breaks the usual notion of the American reader of the head of a democratic state. This leads to the formation of a negative image of the Russian leader among Americans.

The American press underlines Putin's aspiration to strengthen his autocratic power. Emphasis is placed on the following verbs most frequently used by the American journalists to describe the goals of the Russian president: to override, to put under one's supervision, to establish a connection, establish someone's guilt, to set a limit, to strengthen one's power, to increase the strength.

The ability of the metaphorical model "The President of Russia is the Tsar" to associative deployment testifies its relevance to American journalists. It favors rooting prevailing stereotypes in the American society, figuratively representing Russia as a guarantor of the constitution in terms of the absolute, all-powerful ruler, leading to the formation of a negative image of the Russian leader.

At the same time, we often find examples when Vladimir Putin appears as a caring ruler. However, his main achievement is that he has for- 
warded Russia to the arena of high international politics. E.g.: The Kremlin [Putin] now openly proclaims that the era of the West is over and that Russia has returned to the scene [7]. The biggest part of Russia supports the President. E.g.: And of course Putin is widely seen by Russians as the first strong leader Russia has had in post-Soviet times, making it much more unlikely that his popularity will drop in any event [8].

Readers often perceive relations between countries as relations between human beings. People are inherent in an anthropomorphic view of the world. This may explain the fact of the conceptual idea of a foreign state, as humans with special character, which manifests itself in relations with other countries.

We find the realization of this anthropomorphic metaphor, which is typical of the press in American newspapers. E.g.: Russia is clearly trying to find a new approach. But can she, and in time? (The Newsweek International. 05.10.2016). In this case, the journalist, using the pronoun she, imagines Russia as a human being of the female sex.

Skrebtsova in her studies of media metaphor of modern Russian in the foreign policy discourse, assigns a leading role in the perception of the state as the metaphor of "The state - as a man" [9. P. 116].

However, in the American press Russia does not appear through the metaphorical model "The State as a Man", but through the metaphorical model "Russia is a wild beast".

It should be noted that the most productive for the American press is the metaphorical model: "Russia is a bear". To be more precise, 61 metaphors, which relate to the realization of this metaphorical model, were defined. E.g.: The bear, is surely, the imperial Russia (The Washington Times. 26.02.2007).

Bear as an animal, in any case, is endowed in the human mind with certain characteristics, which in the American journalism are transferred associatively, by similarity, to the image of Russia. The associative development of the indicated metaphorical model "Russia - Bear" occurs through the appeal of American journalists to a completely delineated circle of stereotypical notions of everyday consciousness about this wild animal that gives it quite definite and vivid character traits:

1. Large animal, very strong, terrible predator, which is difficult to hunt and which is difficult to tame. E.g.: The Russian Bear: Vicious, clawing, unreasoning [10]; The scary Russian Bear [11].

2. A Lazy, suffering beast. E.g.: The Russian Bear: ... and yet also slothful, dolorous and dirty [10].

3. It is unpredictable and capable. Despite its awkwardness and seeming simplicity it can make lightning-quick shots and be clever and careful. E.g.: It [the United States and its foreign policy establishment] now seems keen on poking the Russian bear - until the bear reacts and a new confrontation develops [12]. 
4. A great danger in the winter is represented by bears which, for some reasons, have not hibernated and staggered through the forest. E.g.: The bear was not gone; he was only hibernating. And he is back [13].

Currently, the stereotype that underlies the metaphorical model "Russia - Bear" is in the focus of our attention. But, we managed to find only a few examples that testify to this process of breaking the stereotype. E.g.: Listening to no one Russia is not such a bear as $\underline{\text { it was }}$ before (The Time. 12.08.2006);

- E.g.: Why the U.S. needs to dance with the Russian Bear? (latimes.com 30.09.2015);

- E.g.: Russian Bear supplants American Eagle in Syria [14].

Thus, Russia is characterized in the American media through the metaphor of the "Russia as a Bear", which emphasizes the Russian aggression and the danger posed by it. Nevertheless, it is necessary to pay attention to what the metaphorical model of the "Russia - Bear" is popular in Russia itself, but it gets a positive content. The whole world knows that the bear is a national symbol of Russia (the bear is endowed with a good-natured character in Russian fairy tales, although not without flaws. It is the symbol of the Olympic Games held in Moscow in 1980, and also, the smiling bear in Sochi in 2014).

Nevertheless, Russia has its friends and enemies, with whom it is able to:

- to have a dialog. E.g.: Russia actually has more say in world affairs than they [unpopular leaders of Ukraine] do [15];

- to flirt. E.g.: Moldova eyes Russia's embrace as flirtation with Europe fades [16];

- to confront. E.g.: Russian-Ukrainian Conflict Spilling Beyond Borders And Into Natural Gas Markets [17];

- to find support. E.g.: Russia will find in Beijing the support and encouragement [18];

- it is also punished by imposing sanctions on it. E.g.: Unfortunately... sanctions on Russia have been largely unsuccessful [19].

Despite all this, Russia remains dangerous for its unpredictability and influence, which it regained. Russia is not perceived by the American press as equal to the US country, but is perceived as a wild beast, which even when wounded remains dangerous, and it is very difficult to tame it. E.g.: Still, Russia's ability to cause harm to itself and to others in the cause of proving its greatness should never be underestimated (The Newsweek International. 06.12.2006); We need one [a new president] who can... grin down an angry bear [6].

Describing the relations between Russia and the United States, the US media are constantly using metaphors, emphasizing the hostile relations between these two countries. 


\section{A metaphorical description of relations between Russia and the United States}

The metaphorical model "there is the Cold war between Russia and the United States" (the model is revealed in 79 metaphorical words) goes back to the national stereotype "Russia is the enemy". E.g.: Eighteen percent of Americans consider Russia to be the United States' greatest enemy today [20].

Americans believe that Russia is a "rude" state. E.g.: Putin's Russia has just... transformed into a rogue state [21].

The relations between Russia and America have always been in the focus of attention by the American journalists. The reason for this is tension between the two countries, which gives enough grounds for expression and evaluation. Vladimir Putin's coming to power has not changed the "political orientation" and course of Russia. The image of the relations between Russia and the United States created a metaphor, it does not change the negative connotation. "Military metaphor" is revealed through a number of concepts:

- "The cold war". E.g.: By the logic, the U.S. is now in a new Cold War [with Russia] [22].

- Returning to the Cold War. E.g.: some will call it a return to the Cold War days [Hall: 2016]; Russian submarine activity in the North Atlantic has climbed back up to Cold War-era [23].

War can be represented through:

- "strategy" E.g.: Russia's unclassified national security strategy says that nuclear weapons would be used only in the event of an attack with weapons of mass destruction on Russia or one of its allies [24];

- "confrontation". E.g.: The pragmatists say that discourse on values throws us back to the old confrontation [7];

- "agression". E.g.: Additionally, in light of Russia's aggressive behavior and a desire to use its nuclear and ballistic missile leverage to blackmail the U.S. and its allies, the United States should plan for a comprehensive-layered ballistic missile defense system capable of shooting down all ballistic missiles [25];

- "threat". E.g.: Forty-nine percent also now see Russia's military power as a critical threat [20].

Some American journalists reflect on what state is a big threat: Russia or IGIL (a forbidden organization in Russia)? E.g.: Who [is] the greater threat to world peace... - the Islamic State or Putin's Russia? [26].

As we have seen, the metaphor of the "cold war" continues to exist in the American press, describing not only the relations between Russia and the United States in the past but in the present as well.

Against the background of all the material we studied, only one analytical article is selected, designed for a more thoughtful reader: "Russia Is Not the Enemy" in "The Boston Globe" newspaper. Here we can see a de- 
parture from the "Cold War" stereotypes when describing the relationship between Russia and the United States.

Stephen Kinzer, the author of the article, disagrees with the position of indiscriminate criticism of Russia. Referring to the national stereotype "Russia is an enemy", he changes the accents of general perception. The journalist talks about the fact that the US policy towards Russia looks deliberately hostile. E.g.: The United States has constructed such a fantasy by turning Russia into an enemy. Having Russia as an enemy is strangely comforting to Americans Emotion argues that Russia is a troublemaker because it refuses to play by our rules, and must be confronted and punished. Reason should reply that Russia is a legitimate power, cannot be expected to take orders from the West, and will not stand quietly while the United States promotes anti-Russia movements on its borders. The most important reason it is folly to turn Russia into an enemy [27].

This article is the exception that proves the rule. That is why it is allocated.

Thus, out of the 253 metaphorical words considered, found in American published texts, only 18 metaphors are directed towards the positive image of Russia. Most of the metaphorical usage (235) is an implementation of the metaphorical models, creating a negative image of Russia.

Conclusions on the analysis of the metaphorical models, encountered in the modern American press for creating the image of Russia, are represented in Table.

The image of Russia in the modern American press

\begin{tabular}{|c|c|c|c|}
\hline $\begin{array}{c}\text { Modern American } \\
\text { press }\end{array}$ & $\begin{array}{c}\text { President of the } \\
\text { country (amount) }\end{array}$ & $\begin{array}{c}\text { Characteristics of the } \\
\text { country (amount) }\end{array}$ & $\begin{array}{c}\text { Relations between } \\
\text { the US and Russia } \\
\text { (amount) }\end{array}$ \\
\hline Metaphorical models & $\begin{array}{c}\text { "Russian President }- \\
\text { Tsar" (120) }\end{array}$ & $\begin{array}{c}\text { "Russia - bear" } \\
(114)\end{array}$ & $\begin{array}{c}\text { "There is the Cold } \\
\text { war between the US } \\
\text { and Russia" (129) }\end{array}$ \\
\hline
\end{tabular}

\section{Conclusion}

To sum up, it should be noted that the use of metaphorical modeling techniques along with the use of contextual and comparative analysis reveals patterns in the organization of the American political discourse. Analysis of the political metaphors encountered in the contemporary American journalism provides sufficient sources for studying the national picture of the world, examining national stereotypes of perception of a foreign country and confirms the important role of metaphors in conceptualizing and categorizing the world. 
When studying the conceptual metaphors of a particular language, both the features of national consciousness and the national picture of the world are explored simultaneously from various angles. Many of these metaphors "guide" the perception of reality, the understanding of the phenomena and events that occur, and determine the national characteristics of the communicative behavior of people.

As a final remark, metaphorical models represented in the research give right to think that the construction of "enemy image" is based on three positions (the negative image of the Russian leader, the negative characteristics of Russia, the negative characterization of relations between Russia and the United States).

\section{References}

1. Chudinov A. (2006) Political Linguistics. Moscow: Flinta, Nauka.

2. Chudinov A. (2003) Metaphorical Mosaic in the modern political communication. Ekaterinburg: Ural. gos. ped. un-t.

3. Motyl A. (2014) Will Putin's Successor be worse? 22.09.2014 http://www.worldaffairsjournal.org

4. Lewis J. (2015) Tsar Putin defends the West. 14.12.2015 http://www.americanthinker.com

5. Harper Jr. (2014) Vladimir Putin using Peter the Great tactics. 06.03.2014 http://www.washingtontimes.com

6. Babbin J. (2016) The David Crocket solution to Putin. 25.01.2016 http://www.washingtontimes.com

7. Shvetsova L. (2015) How the west mischarged Russia, Part II the Pragmatists. 20.01.2015 http://www.the-american-interest.com

8. Hall S. (2016) Putin's Russia is more stable than it seems. 23.01.2016 https://www.stratfor.com

9. Skrebcova T. (2011) Cognitive linguistics. SPb.: Filologicheskij fakul'tet SPbGU.

10. Vlahos M. (2015) Putin's and Russia's Quest for Identity and Belonging. 15.02.2015 http://www.theglobalist.com

11. Bayer A. (2015) Vladimir Putin: The Antithesis of a Success Story. 18.03.2015 http://www.theglobalist.com

12. Zukerman A. (2014) The Ukrainian Crisis: A Question of the World's Future. 27.03.2014 http://www.theglobalist.com

13. Horsey D. (2014) Putin's Ukraine incursion brings back the bad old bear. 25.04.2015 $\mathrm{http}: / / \mathrm{www}$.latimes.com

14. Opall-Rome B. (2015) Russian Bear Supplants American Eagle in Syria, Beyond. 27.09.2015 http://www.defensenews.com

15. Rapoza K. (2015) Like It Or Not, Russia Must Be Taken Seriously. 07.10.2015 http://www.forbes.com

16. Higgins A. (2015) Moldova Eyes Russia's Embrace as Flirtation With Europe Fades. 21.05.2015 http://www.nytimes.com

17. Silverstein K. (2014) Russian-Ukrainian Conflict Spilling Beyond Borders And Into Natural Gas Markets. 03.03.2014 http://www.forbes.com

18. Chang G. (2014) Russia's New 'Energy Alliance' with China. 10.09.2014 http://www.worldaffairsjournal.org

19. Ashford E. (2015) The Failure of Sanctions on Russia. 23.12.2015 http://newsweek190.rssing.com 
20. Sherfinski D. (2015) Americans agree with Mitt Russia is now the greatest enemy of U.S. 15.02.2015 http://www.washingtontimes.com

21. Motyl A. (2015a) Putin's Misguided Move in Syria. 25.09.2015. http://www.worldaffairsjournal.org

22. Tamkin E. (2016) Vladimir Putin's American apologists have a point. 24.01.2016 http://theweek.com

23. Majumdar D. (2016) NATO's Nightmare: Russian Sub Activity Rises to Cold War Levels. 02.02.2016 http://www.nationalinterest.org

24. Pifer S. (2016) Pay attention, America: Russia is upgrading its military. 03.02.2016 http://www.the-american-interest.com

25. Dodge M. (2015) How the Obama administration changed our missile defense strategy. 30.01.2015 http://dailysignal.com

26. Motyl A. (2015b) Putin vs. ISIS: which threatens the West more? 09.12.2015 $\mathrm{http} / / /$ www.worldaffairsjournal.org

27. Kinzer S. (2015) Russia is not the enemy. 20.09.2015 https://www.bostonglobe.com

\section{Information about authors:}

Ilyushkina Maria, $\mathrm{PhD}$, Associate Professor of the Department of Linguistics and Professional Communication in Foreign Languages, Ural Federal University (Yekaterinburg, Russia).E-mail: ilyushkina_maria@mail.ru

Chudinov Anatoly, D.Sc. (Philology), Professor, Head of the Department of Intercultural Communication, Rhetoric and Russian as a Foreign Language, Ural State Pedagogical University (Yekaterinburg, Russia). E-mail: ap_chudinov@mail.ru

\section{МЕТАФОРИЧЕСКОЕ МОДЕЛИРОВАНИЕ ОБРАЗА РОССИИ В СМИ (НА МА- ТЕРИАЛЕ АМЕРИКАНСКОЙ ПРЕССЫ)}

Илюшкина Мария Юрьевна, кандидат филологических наук, доцент кафедры лингвистики и профессиональной коммуникации на иностранных языках Уральского федерального университета имени первого Президента России Б.Н. Ельцина (Екатеринбург, Россия). E-mail: ilyushkina_maria@mail.ru

Чудинов Анатолий Прокопьевич, доктор филологических наук, профессор, заведующий кафедрой межкультурной коммуникации, риторики и русского языка как иностранного Уральского государственного педагогического университета (Екатеринбург, Россия). E-mail: ap_chudinov@mail.ru

Аннотация. Проанализированы способы метафорического моделирования образа России в современной американской прессе. Предпринятый анализ направлен на изучение значимости концептуальных метафор в раскрытии и понимании национальной картины мира и национальных стереотипов. Выявленные метафорические модели определяют три преобладающие негативные тенденции в репрезентации образа России и современного российского политического дискурса, а именно: отрицательный образ лидера страны, негативный облик страны, конфликты во взаимодействии между Россией и США, основанные на метафорических «образах врагов». Исследование метафорического моделирования образа России в современных СМИ США представляется перспективным, так как позволяет классифицировать и описать материал, учитывая ситуативный, контекстуальный и лингвокультурологический аспекты. В системе концептуальных метафор каждого народа есть немало составляющих, отражающих культурные особенности и яркие национальные стереотипы. В центре нашего внимания оказались публицистические тексты, адресованные читателям с разными интересами и интеллектуальными запросами, в исследовании которых применялся компаративный метод. Сопоставительное исследование разных политических дискурсов способствует углубленному изучению национальной культуры и особенностей мировосприятия, так как позволяет выявить - наравне с общими - национально специфические модели, а также 
выдвинуть предположение об общенациональной или индивидуальной природе факторов, обусловливающих специфичность той или иной модели в дискурсе. Более того, в настоящей статье с привлечением корпусных технологий проанализирован блок политических метафор, задействованных в формировании образа России в американских СМИ, выявлены доминантные метафорические модели, дискурсивная характеристика моделей, прагматический потенциал. Для исследования политической метафоры привлекались методы корпусной лингвистики, что дает возможность наблюдать употребление единиц языка в естественном контексте. Таким образом, корпусные технологии позволяют исследователям работать с большими массивами данных, изучать лексические единицы в среде их естественной коммуникации, получать достоверные статистические данные. Тем самым корпуса являются источником новых данных, что так необходимо для лингвистических исследований.

Ключевые слова: метафорическое моделирование; средства массовой информации; образы; стереотипы; национальная картина мира; Россия; США.

\section{Грантовая поддержка}

Исследование выполнено в рамках гранта Российского фонда фундаментальных исследований: проект № 19-012-00465 А «Лингвополитическая персонология: когнитивный поворот». 